\title{
ANALYSIS OF VILLAGE DEVELOPMENT BASED ON VILLAGE FUNDS (CASE STUDY OF SEI ROTAN VILLAGE, PERCUT SEI TUAN DISTRICT)
}

\author{
Mahyudin Situmeang \\ Program Studi Administrasi Negara, Fakultas Administrasi \\ Universitas Pembinaan Masyarakat Indonesia \\ Jl. Teladan No.15 Teladan Barat, Kota Medan, Sumatera Utara, 20214, Indonesia \\ e-mail: mahyudinsitumeang@gmail.com
}

Received: 22 December 2020, Repaired: 20 Januari 2021, Approved: 05 February 2021

\begin{abstract}
So far, the government has realized the village fund budget every year. Therefore, every village government must develop plans that can support the community's welfare by prioritizing community priorities or needs. The purpose of this study was to analyze the village fund allocation policies in village development planning. This type of research is descriptive qualitative. Data collection techniques are carried out by observation and interviews, then analyzed using qualitative analysis techniques. Data processing is done by reducing, categorizing, and concluding, and presenting data. The results of this study found that so far, the village fund allocation policies have been implemented well, such as meeting basic needs, building facilities and infrastructure, developing local economic potential, and utilizing natural and environmental resources. Likewise, the face of the regional planning of Sei Rotan Village using the Village Fund budget has been able to leverage Village welfare. However, the problem is that the planned program has not been fully fulfilled due to limited human resources and funding. The regional development realized with village funds are roads, bridges, and drainage at flood-prone points. The land use pattern of the Sei Rotan area shows the expansion of the built-in land in the form of developer housing and community villages.
\end{abstract}

Keywords: Village Fund, Development, Territory

\begin{abstract}
Abstrak
Pemerintah sejauh ini telah merealisasikan anggaran dana desa setiap tahunnya. Oleh karena itu, setiap pemerintah desa wajib membuat perencanaan pembangunan yang dapat mendukung kesejahteraan masyarakat dengan mengutamakn perioritas atau kebutuhan masyarakat. Tujuan penelitian ini adalah untuk menganalisis kebijakan alokasi dana desa dalam perencanaa pembangunan wilayah desa. Jenis penelitian ini adalah deskriptif kualitatif. Tehnik pengumpulan data dilaksanakan dengan observasi dan wawancara, kemudian dianalisis menggunakan tehnik analisis kualitatif. Pengolahn data dilakukan dengan mereduksi, mengkategorisasikan, dan menyimpulkan dan menyajikan data. Hasil penelitian ini menemukan bahwa selama ini kebijakan alokasi dana desa telah dilaksanakan dengan baik seperti pemenuhan kebutuhan dasar, pembangunan sarana dan prasarana, pengembangan potensi ekonomi lokal, dan pemanfaatan sumber daya alam dan lingkungan. Demikian halnya wajah perencanaan wilayah Desa Sei Rotan dengan menggunakan anggaran Dana Desa telah mampu mengungkit peningkatan kesejahteraan Desa. Namun permasalahannya belum sepenuhnya program yang direncanakan terpenuhi dikarenakan keterbatasan sumberdaya manusia dan anggaran. Adapun pengembangan wilayah yang terealisasi dengan dana desa adalah pembangunan jalan, jembatan, drainase pada titik-titik rawan banjir. Pola pemanfaatan lahan kawasan Sei Rotan memperlihatkan perluasan lahan terbangun dalam wujud perumahan pengembang maupun perkampungan masyarakat.
\end{abstract}

Kata kunci: Dana Desa, Pembangunan, Wilayah 


\section{INTRODUCTION}

Development that involves the community can also be called participatory action. The implementation of participatory development is a logical consequence of the demands for reform and openness desired by the community since the fall of the New Order regime, which is also supported by the principles of governance contained in Law no. 32 of 2004 concerning Regional Government which mandates the importance of implementing regional autonomy, democratization, community participation and decentralization of authority to carry out governance and development at the regional level and village communities can be more independent in solving problems of life and life together with the village government in their villages.

Village conditions are illustrated by the composition and number of village residents that are very large and identical to poverty. The number of poor people in rural areas tends to be more significant when compared to urban areas. One of the root causes of poverty problems in rural areas is the imbalance of relations with metropolitan areas, which tends to be detrimental to rural areas. The refore it is necessary to strengthen rural areas by placing the Village as the basis for decentralization.

Although the Village should be the basis of decentralization and play a role as a self-governing community, most villages face regional development problems, namely, first because the APBDes is small and the source of income is very dependent on very little assistance. Second, the village community's welfare is low, so it is difficult for the Village to have a high Village Original Income (PADes). Third, the problem was followed by the quiet Village Operational Fund to run services. Fourth, it is no less important that many development programs enter the Village but are only managed by the Dinas. Such a program draws criticism that this program does not provide access to learning for the Village. The program is top-down so that it is not in line with the Village and its community's needs, which continuously weakens the village community's position in developing their Village.

In line with regional autonomy and government programs' launch, the efforts to accelerate development services in rural areas through the Village Fund Allocation Budget (ADD) provide a breath of fresh air. They are seen as making a significant contribution to supporting rural areas' development to support life improvement in the Village. They can provide more flexibility in determining village development needs following the proposed Village Fund Allocation (ADD) programmed by the government according to the Regional Regulation of Deli Serdang Regency No. 6 of 2015 and seen to be able to accelerate the rate of growth and development of community life in the Village.

The exciting thing about this program is seen as very meaningful in supporting the development budget in various aspects in the sei rattan village, which is at the same time very appropriate to support the development of Sei Rotan village as a centre of economic and social growth for rural communities, geographically located very close to Medan city and district city centre Deli Serdang is Lubuk Pakam.

The government has done many things to develop the Region, but it is still dead. So far, there is still an imbalance in regional development in villages and cities. Regional development also does not touch and pay attention to the unique characteristics of rurban (rural-urban) areas. This area is located on the outskirts, especially in Sei Rotan Village, influenced by the city's character (both physical and nonphysical). On the other hand, it still has the name of the Village. Without special attention in its development, this Region will increasingly accept the implications of complex city problems, and its potential origins will fade. For this reason, there is a lot of potential in this kind of area that needs to be managed and developed in an orientation to increase the welfare of the 
community and realize sustainable regional governance (Sulistiyani, 2004).

\section{RESEARCH METHOD}

Judging from the object and method of analysis used, this research is included in the qualitative descriptive study. This research attempts to describe an accurate picture of the phenomena in village funds management, especially Village Fund Allocation in Sei Rotan Village, Percut Sei Tuan District, Deli Serdang Regency. The data used in this study are primary data obtained from informants by interviewing, observation, documents, and questionnaires. Data processing begins by examining all data that has been collected from various sources, namely data in the form of words, interviews, documentation, and secondary data, by selecting them to find the required data. Furthermore, placing the data in their respective categories, the techniques used to compare the data obtained from informants and documentation. The interviews were done into transcripts by playing back the recorded interviews and listening carefully. The researcher wrote the words heard according to the recording in text form and then performed data reduction.

Data reduction is made by making abstractions, namely taking and recording useful information following the research context. The language is written following the informant's speech. Researchers are required to reduce interpretation. Then displayed in the transcript or text form and analysis by:

1. qualitative data coding is done to reduce information into themes and categories.

2. coding involves various processes of sorting information, developing coding categories, and creating themes and patterns. Coding analysis includes:

a. open coding, coding from the transcript of the field data interview into specific codes.

b. Axial coding, categorizing Open Coding, which has the same characteristics. c. Selective coding, sorting out which axial coding is following the theoretical study to be studied.

Furthermore, looking for categorical information to obtain an understanding concerning all variables, for example, the researcher takes one document (one interview), continues by making a "list of topics," then by "coding the topic," and to "data" and "identification." The topic is adjusted to the substance of the research so that it is possible to "reduce the topic." Then the most "descriptive" words were selected for each topic. The researcher makes the "final decision for each category" and continues by organizing and placing the data under each category, if necessary, to recode the data. Based on the data analysis technique mentioned above, this research was carried out utilizing a data comparison process.

Data from observations, scientific information, and various literature references are compared and reviewed with data based on interviews. This method also allows the crosschecks of data obtained in the field and data from literature studies. Furthermore, they are grouped or classified according to the objectives achieved through research. The technique used is a qualitative descriptive analysis technique.

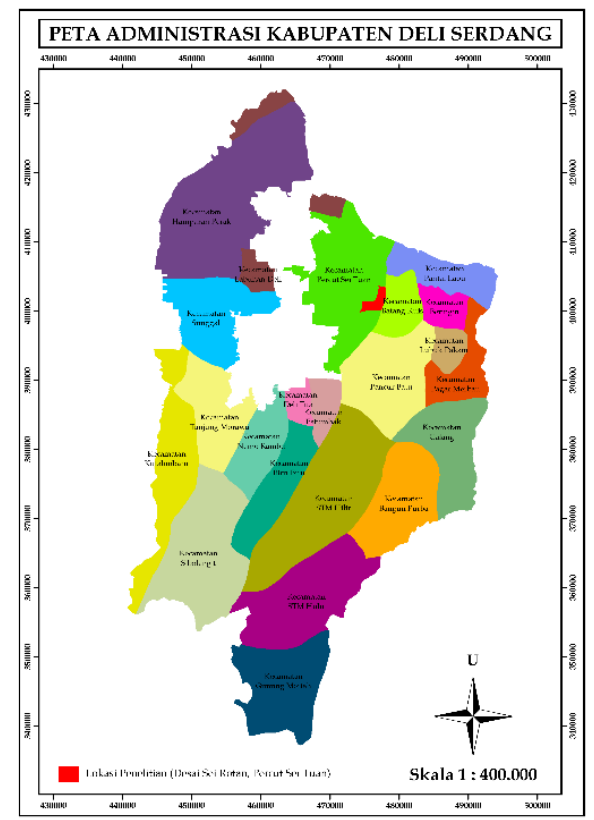

Figure 1. Regional Map of Sei Rotan Village 


\section{RESULTS AND DISCUSSION}

\section{Overview of Sei Rotan Village, Percut Sei Tuan District}

Percut Sei Tuan Subdistrict during the colonial period of the Dutch Government around the 19th century were two Minor Kingdoms, namely Percut Vocational and Sei Tuan Vocational Protectorate the Deli Sultanate until the early proclamation of the Republic of Indonesia. Percut Sei Tuan Subdistrict is the Government Center and the Center for the largest Deli tobacco plant with the nickname "Dollar Land." During the Republic of Indonesia's reign, the Percut Vocational School and Sei Tuan Vocational Studies were merged into one Percut Sei Tuan District area, and a Camat named Des currently heads. Timor Tumanggor, M.AP, leads the District and has become a historical successor in the District, especially in the Percut Sei Tuan District.

Location and Geography Percut Sei Tuan District has an area of $190.79 \mathrm{~km} 2$ consisting of 18 villages and two sub-districts. 5 Villages from the Percut Sei Tuan Subdistrict are Coastal Villages with an altitude from sea level ranging from 10-20 m with an average rainfall of 243 per cent. The centre of government is located at Jalan Medan Batang Kuis, Bandar Klippa village. Percut Sei Tuan Subdistrict, Deli Serdang Regency with boundaries:

1. North: Malacca Strait

2. Eastside: Batang Kuis District and Labu Beach

3. West side: Labuhan Deli and Kodya Medan District

4. South side: Kodya Medan

Percut Sei Tuan Subdistrict, Deli Serdang Regency, has rivers and those located in Tembung Village, Bandar Khalipah Village, Bandar Setia Village, Laut Dendang Village, Sampali Village, Cinta Rakyat Village, Cinta Damai Village, Saentis Village, Percut Village. Percut Sei Tuan District, Deli Serdang Regency has a distance from the District Capital to the Village / Kelurahan Office.
Table 1. The distance from the capital city of Percut Sei Tuan District to the Village/ Sub-district Office

\begin{tabular}{|c|l|c|}
\hline No & \multicolumn{1}{|c|}{ Village } & Distance (Km) \\
\hline $\mathbf{( 1 )}$ & \multicolumn{1}{|c|}{$\mathbf{( 2 )}$} & $\mathbf{( 3 )}$ \\
\hline 01 & Amplas & 5,00 \\
\hline 02 & Kenangan & 6,00 \\
\hline 03 & Tembung & 0,30 \\
\hline 04 & $\begin{array}{l}\text { Sumber Rejo } \\
\text { Timur }\end{array}$ & 2,50 \\
\hline 05 & Sei Rotan & 3,00 \\
\hline 06 & $\begin{array}{l}\text { Bandar } \\
\text { Klippa }\end{array}$ & 0,50 \\
\hline 07 & $\begin{array}{l}\text { Bandar } \\
\text { Khalipah }\end{array}$ & 1,50 \\
\hline 08 & Medan Estate & 3,00 \\
\hline 09 & Laut Dendang & 6,00 \\
\hline 10 & Sampali & 7,00 \\
\hline 11 & Bandar Setia & 4,00 \\
\hline 12 & Kolam & 5,00 \\
\hline 13 & Saentis & 15,00 \\
\hline 14 & Cinta Rakyat & 16,00 \\
\hline 15 & Cinta Damai & 20,00 \\
\hline 16 & $\begin{array}{l}\text { Pematang } \\
\text { Lalang }\end{array}$ & 22,00 \\
\hline 17 & Percut & 20,00 \\
\hline 18 & Tanjung Rejo & 18,00 \\
\hline 19 & $\begin{array}{l}\text { Tanjung } \\
\text { Selamat }\end{array}$ & 16,00 \\
\hline 20 & $\begin{array}{l}\text { Kenangan } \\
\text { Baru }\end{array}$ & 7,00 \\
\hline
\end{tabular}

Source : Kantor Camat Percut Sei Tuan, 2019

Village Administration is the government affairs administration by the Village Government and the Village Consultative Body to regulate and manage the local or Village community's interests. The village government, based on Law Number 32 of 2004 concerning Village Regional Government, is eaten as a legal community unit that has jurisdictional boundaries, has the authority to regulate and manage the interests of the local community based on their origins and local customs, which are recognized and established in the national government system and is located in the district/city, as referred to in the 1945 Constitution of the Republic of Indonesia. The rationale for regulating the village government is diversity, participation, 
genuine autonomy, democratization, and community empowerment. Law number 32 of 2004 recognizes the village government's autonomy or by other designations. The village government can be assigned or delegated from the government or local government to carry out certain government affairs.

As a manifestation of democracy following the provisions of Law no. 32 of 2004, the government in the village government structure is formed by the Village Board of Trustees (BPD) or other designations that are adapted to the culture that develops in the Village concerned, which functions as a regulatory and controlling agency in the administration of village government, such as in the creation and implementation of Village Regulations, Budget Village Income and Expenditure, and Village Head Decrees. In the Village, a community institution is formed which acts as a partner of the village government in empowering the village community. Thus the village government is the village head along with village officials and members of the BPD. The village head is responsible to the village people whose accountability procedures and procedures are conveyed to the regent or mayor through the camat. The Village Head is obliged to provide a statement of his accountability report and convey information on his accountability's main points to the Village Consultative Body. However, it must still provide opportunities for the community through the Village Consultative Body to inquire and request further information regarding matters relating to the account in question. Following Government Regulation Number 72 of 2005 Chapter IV article 11, the village government consists of the Village Government and the BPD.

Then following the Government Regulation of the Republic of Indonesia Number 72 of 2005 concerning the definition of a village, namely a standard community unit that has territorial boundaries that are authorized to regulate and manage the interests of the local community, based on local origins and customs which are recognized and respected in the State Government system. The Republic of Indonesia. Village Government is the organizer of government affairs by the Village Government and the Village Consultative Body to regulate and manage the local community's interests based on local origins and customs recognized and respected in the Government system of the Unitary State of the Republic of Indonesia.

Thus, the Village Government or what is referred to by another name is the Village Head and Village Officials as village government administration elements. The Village Consultative Body, or what is referred to by another name, from now on abbreviated as BPD, is an institution that is the embodiment of democracy in the village government's administration as an element of village government administration.

Village Fund Allocation is a fund allocated by the Regency / City Government to villages, which originates from a portion of the central and regional financial balancing funds received by the Regency / City. Village Revenue and Expenditure Budget, referred to as APBDesa, is the village government's annual financial plan discussed and mutually agreed upon by the Village Government and BPD, stipulated by a Village Regulation. Village Regulations are laws and regulations made by BPD together with the Village Head. Village community development is an effort carried out in a planned and sustainable manner to achieve the dreamed village community to achieve a prosperous society (changes in lifestyle and behaviour patterns from traditional thinking to modern society). Here in after abbreviated as ADD, Village Fund Allocation is the balanced fund received by the Region in the Regional Budget of Deli Serdang Regency after deducting the Special Allocation Fund.

Village development is all development activities in rural areas, covering all aspects of the entire community's life carried out in an integrated manner by developing self-help gotong royong. The success indicator of village development is a real improvement in the community's living conditions because 
development is always improving from a better condition.

\section{Regional Development of the Percut Sei Rotan Village}

The village funds disbursed by the government since 2015 have not fully shown a significant impact on the welfare of the community in the Village. One reason is that most of the village funds are spent in urban areas. There are still many poor villages because village funds are not right on target and do not focus on superior village products. Most of the village funds are, in fact, "taken" out of the Village. Improvement must be carried out immediately so that village funds have a broad impact on improving rural communities' welfare and development. Therefore, the government has made a development priority scale. This is because the village funds in one fiscal year are not sufficient to finance all village development. The Village must make a priority scale so that village development can be carried out in stages based on that scale. " "The delay in disbursement so far is more because the village or region has not completed these requirements," he said. He said the main problem was the village human resource (HR) readiness in preparing the required documents. There are still many villages that have not compiled village regulations (pendes) regarding the APBDesa. The problems in each Region or Village are different in the development of different village areas. For example, in the first and second years of implementation, almost $90 \%$ of village funds were distributed equally to each Village without distinguishing certain conditions, such as area size, population size, and poverty level. Areas where the territory is not too large, or the population and poverty conditions are not too high, can find the root of the Village's problem. The right solution can be immediately disbursed. Meanwhile, some villages are still struggling with problems that existed before the village funds were disbursed. Various deficiencies and problems in the management of village funds have been corrected. Villages that have not managed the budget will focus on the central government's attention through various interventions, such as cashintensive programs. This year, the government is targeting 100 villages in 10 districts to be targets of cashintensive programs. Until 2019, it is targeted that there are 1,000 villages in 100 districts. "This is one of the solutions that the government has made to anticipate various disadvantages or underdevelopment in the Village, such as the high stunting rate of children under five, minimal employment, high unemployment, and high poverty conditions. When viewed from the need, the funds that went into the Village were still insufficient. To that end, the PDTT Ministry of Village is looking for other sources to encourage development in the Village. One of them is developing Superior Products for Rural Areas (Prukades), where previously poor villages are encouraged to have superior products with a large production scale, thereby increasing the Village economy. There are still many villages that are poor because they do not focus on certain superior products. Also, village products are sold in raw materials or raw materials, so their economic value is small. To sell processed products, rural communities need machines and other facilities with large enough capital. Quantitatively, in just three years, village funds have succeeded in building infrastructures such as roads, drainage, and bridges.

Village planning should be necessary to realize the village population's welfare so that formulating social goals and spatial arrangements for activities to achieve goals can be carried out properly. The existence of Law number 6 of 2014 concerning Villages (Village Law) brings the population in the Village to be more prosperous through 4 (four) main aspects, namely the fulfilment of basic needs, development of facilities and infrastructure, development of local 
economic potential, and utilization of natural and environmental resources. (Article 78, paragraph 1). To support the Village Development, there is a fairly large allocation of funds flowing to the Village. Article 72 paragraph (4) stipulates that at least $10 \%$ of the regional transfer funds in the State Revenue and Expenditure Budget (APBN) will flow to the Village. Based on the budget simulation, each Village will receive an average of IDR 1.44 billion in 2014.

For these funds to significantly impact the Village population's welfare, each Village must plan its use carefully. Therefore, Village development planning as mandated by Article 79 and Article 80 is the main factor to be implemented properly, correctly, and.

Seeing some important things that need to be considered from village development planning. First, Village development planning must be able to cover priority programs for increasing welfare in documents. With such a large flow of funds, the Village will become an attractive target for many interest groups, both from internal to the Village itself and outside.

The next important thing is how to synchronize Village development plans with development plans at higher levels, namely regional and national development plans. Article 79 paragraph (1) affirms that Village development plans are prepared with Regency/City development planning authority. A vital role for districts/cities in accommodating and disbursing village funds after a program proposal from the Village will present its challenges. The varying capacities of districts/cities in assisting the Village may result in DAD's utilization (Regional Allocation Fund) in the Village, which does not follow District / City development's objectives and priorities.

The face of Sei Rotan Village's regional planning by using the Village Fund budget has increased the village welfare. However, the problem is that the planned program has not been fully fulfilled due to limited human resources, budget, and human resources. Sei Rotan's village government requires government commitment in village empowerment in government policies regarding planning about funding transfers to overcome this problem. The government's policies include, first, using planning as an aspect that limits village community access to fund transfers.

This means that villages unable to compile documents will not be transferred the allocation of funds that are due to them. This policy will effectively force the Village to make plans. Still, it is necessary to be aware of the emergence of "brokers" to prepare planning documents that may be played by educated people living in the village or government officials in the supra village.

Second, strengthening social capital, which has been the strength of Sei Rotan Village. Village fund policies have played a role in increasing the real income of rural communities. In line with the research findings by (Abdillah \& Fachrurozy, 2017) of $18 \%$ of the people interviewed and inequality in community income has not improved so much after the government provided village funds. Second, the village fund policy has a role in adding physical facilities and infrastructure in rural areas, which is recognized by $47 \%$ of the community.

Third, village funds management in planning, implementation, supervision, and transparency and their impact on the community have been appropriately implemented. However, it is still not fully in line with rural communities' expectations. Fourth, given the many obstacles encountered in managing village funds, village funds' expected impact on economic development and infrastructure in rural areas in the short term can be quite good.

The Village Fund Allocation Budget (ADD) presence provides opportunities for villages to be more advanced and independent. Still, on the other hand, it is seen that the implementing elements of the Village Fund Allocation Budget (ADD) of the Village Government and Village 
Institutions and the community indicate that they have not been able to implement the Village Fund Allocation Budget (ADD) with well come.

To regulate the implementation of Village Fund Allocation in more detail, the Government of Deli Serdang Regency then issued a Regulation of the Regent of Deli Serdang Regency Number 714 of 2016 concerning Procedures for Distribution, Determination of Details, and Technical Guidelines for the Use of Village Funds in Deli Serdang Regency in 2016 Fiscal Year. Well.

Distribution of Village Fund Allocation (ADD) The use of Village Fund Allocation, namely the Village Fund Allocation received by the Village Government in the amount of $30 \%$, is used for implementing Village Government's operational costs. The operating prices include (a) Village government expenditures such as expenditures for goods, maintenance expenses, official travel costs, meeting costs, stationery, and others amounting to $20 \%$. (b) Operational and BPD allowances consist of BPD management and member allowances, official travel, meeting fees, and $25 \%$ stationery. (c) Additional welfare of the Village Head and Village Officials by $15 \%$. (d) Assistance for Village Institutions' operational costs that are formed, recognized, and fostered by the Village Government include LPMD, RT, RW, PKK, Karang Taruna, and LINMAS by $40 \%$. Then $70 \%$ of the ADD received by the Village Government is used for empowering village communities. Empowerment of rural communities includes (a) prioritized physical development expenditures to support poverty alleviation, improve education, rural communities' health, and strengthen community services. (b) Nonphysical development spending in the context of strengthening the economy of rural communities.

As stated in the Deli Serdang Regent Regulation Number 593 of 2016, ADD is intended to finance the Village Government program in carrying out government activities, development, and empowerment of village communities. Meanwhile, the purpose of ADD is:

1. According to their authority, improve village governance administration in implementing government services, development, and village communities empowerment.

2. Increase community organizations' capacity in the Village in participatory planning, implementation, and control of development following the Village's potential.

3. Increasing income distribution, employment opportunities, and business opportunities for rural communities.

4. We are encouraging increased self-help by village communities.

Village Fund Allocation (ADD) is a fund allocated by the District Government for Villages, which comes from the portion of the District's central and regional financial balance funds. Giving ADD is a stimulus for the independence of village communities in carrying out development in their area. This is following the Regent of Deli Serdang Regency's statement, Amri Tambunan, who argued that ADD could be used as a stimulant to motivate the community to participate in the development because if it only relies on government funds, the amount is minimal. With the various legal bases regarding ADD above, Sei Rotan Village, as part of Percut Sei Tuan District, Deli Serdang Regency is obliged to implement ADD policy according to the established legal basis the Village has implemented it. However, in the implementation of ADD, initial research found problems, especially regarding partnerships and community participation in development, were very low.

The successful implementation of a program is inseparable from village community actors who are members of the Village Government and its apparatus, the Village Consultative Body (BPD), Community and Youth Leaders in the Village. Also, internal factors such as local culture, education, views, and attitudes of life, and external factors such as government policies, environment, natural resources, 
telecommunications, and information play a role in determining village development's success through Village Fund Allocation (ADD). In village development.

\section{CONCLUSION}

In practice, regional development planning policies should be necessary to realize the village population's welfare. Formulating social goals and arranging space for activities to achieve goals can be carried out correctly. Law number 6 of 2014 concerning Villages (Village Law) brings the people in the Village to be more prosperous through 4 (four) main aspects, namely the fulfilment of basic needs, development of facilities and infrastructure, development of local economic potential, and utilization of natural and environmental resources. Likewise, the face of the regional planning of Sei Rotan Village using the Village Fund budget has been able to leverage Village welfare.

However, the problem is that the planned program has not been fully fulfilled due to limited human resources and budget. To overcome this problem, Sei Rotan's village government requires a commitment from the central government in empowering the Village in the form of government policies regarding planning in development. Some guidelines can be taken by the government, such as using planning to limit village community access to funding transfers. This means that villages unable to compile documents will not be transferred the allocation of funds that are due to them. This policy will effectively force the Village to plan.

\section{REFERENCES}

Abrahan, F. M., (1982). perspective of modernization: toward a general theory of third world. Karim rusli (penterjemah) modernisasi di dunia ketiga, suatu teori umum pembangunan. (1991). PT. tiara wacana. Yogyakarta.

Alfian, (1980). Kemiskinan struktural: suatu bunga Rampai, yayasan ilmu-ilmu sosial dan HIPIS, Jakarta
Ahimsa putra, heddy shri, (1985). etnosains dan etnometodology: sebuah ilmu perbandingan dalam masyarakat indonesia, majalahilmu-ilmu sosial, agustus jilid XII No.2, LIPI, jakarta.

Anynomous. (1999). Kamus Besar Bahasa Indonesia, Departemen Pendidikan Dan Repuplik Indonesia. Jakarta.

Andi Fahrudin. (2001). Pemberdayaan Partisipasi Dan Penguatan Kapasitas Masyarakat. Bandung: Humaniora

Andie Megantara, Dodi Iskandar, Kuwat Slamet. (2006). Manajemen Perbendaharaan Pemerintahan Aplikasi di Indonesia, Lembaga Pengkajian keuangan Publik dan Akuntansi PemerintahBadan Pendidikan dan Pelatihan Keuangan Departemen Keuangan RI. Jakarta. LPKP RI.

Budi Mulyana, Subkhan, Kuwat Slamet. (2006). Keuangan Daerah Perspektif Desentralisasi Fiskal Dan Pengelolaan APBD di Indonesia. Jakarta: Lembaga Pengkajian Keuangan Publik Dan AkuntansiPemerintahan (LPKPAP)

Boediono. (1982). Teori pertumbuhan ekonomi. Seri Sinopsis Pengantar Ilmu Ekonomi No.4. Yogyakarta.

Budi siswanto. (2010). rekonstruksi pemberdayaan masyarakat di indonesia: landasan filosofi, implementasi dan refleksi. Pidato pengukuhan jabatan guru besar dalam bidang pemberdayaan masyarakat pada fakultas ilmu sosial dan politik universitas merdeka malang. Malang.

Bungin, Burhan. (2003). Analisis data penelitian kualitatif. PT. raja grafindo persada jakarta.

Davis, Kingsley and Wilbert E. moor. (, 1945). some principles of stratification. American sociological review: 10:242-249.

Friedmann, John, furchan. (1992). Empowerment, the politics of alternative development, USA: Cambridge, Blackwell, oxford. 
Frank place, Michelle adato, paul hebink. (2005). understanding rural property and investment in agriculture: an assessment of integrated quantitative and qualitative research in western Kenya. Q-squared working paper no. 10. $Q$ - squared. Centre for international studies. University of Toronto 1 Devonshire Place, Toronto ON M5S 3K7 Canada.

Fridolin ukur. (1992). kebudayaan dayak. Suatu tinjauan umum tentang ciriciri pokok kebudayaan suku-suku asli di kalimantan. Penerbit aditya media. Yogyakarta.

Ghony, Djunaidi. (1997). Dasar-dasar Penelitian Kualitatif: Prosedur Teknik, Dan Teori Grounded. Surabaya: Bina ilmu.

Glasser, Berney G., dan Arsel L. Strauss (1967). The Discovery of Grounded Theory, Aldine, Chicago.

Muh syahbudin latief dan suryatiningsi, (2004). Beberapa Kendala Pemberdayaan Masyarakat Desa Miskin. Yogyakarta: Pusat Penelitian Pembangunan Pendesaan Dan Kawasan Terpadu (P3PK) Universitas Gaja Mada.

Mubyarto, Edhie Djatmiko, Ismaryati, Loekman Soetrisno. (1993). DesaDesa Kalimantan: Studi Bina Desa Pedalaman Kalimantan Tengah. Yogyakarta: Aditya Media.

Mulyana D., 2002. Metodologi Penelitian Kualitatif: Paradigma Baru Ilmu Komunaksih Dan Ilmu Sosial Lainnya. Bandung: Rosdakarya

Michaela, Haug. (2007). Kemiskinan Dan Desentralisasidi Kutai Barat Dampak Otonami Daerah Terhadap Kesejahteraan Dayak Benuaq. Bogor: Center for International Forestry Research (CIFOR). BOGOR

Al-barry, M.Y. (2001). Kamus sosiologi antropologi. Penerbit INDAH. Surabaya.

Peraturan Menteri Dalam Negeri Nomor 13 Tahun 2006 Tentang Pedoman Pengelolaan KeuanganDaerah.
Permendagri Nomor 35 Tahun 2007 Tentang Pedoman Umum Tata Cara Pelaporan Dan Pertanggungjawaban Penyelenggaraan Pemerintah Desa.

Permendagri Nomor 37 Tahun 2007 Tentang Pedoman Pengelolaan Keuangan Desa. Permendagri Nomor 66 Tahun 2007 Tentang Perencanan Pembangunan Desa.

Todaro, Michael p., (1994). Economic Development Edisi Kelima. Singapore. Longman Singapore

Tijilik riwut. (2003). Manaser Panatau Tatu Hilang. Penyunting nilai riwut. Palangkaraya: Pusaka Lima

Tjokrowinoto, Moeljarto. (1993). Strategi alternatif pengentasan kemiskinan. Makalah di sampaikan dalamseminar bulanan P3PK. Yogyakarta: Universitas Gajah Mada

W.R. Geddes. (1968). Nine Dayak Nights, London. New York: Basic Books

Yulianti, Yayuk. (2003). Sosiologi Pendesaan. Malang: Universitas Malang

Zaitlin, Irving M. (1998). Memahami kembali sosiologi: Kritik Terhadap Teori Sosiologi Kontemporer. Yogyakarta: Gadjah Mada University Press. 